Onan, B. ve Özçakmak, H. (2014) Türkçe deyimlerde dil farkındalığı ve işlevsel dil kullanımı. Ana Dili Eğitimi Dergisi, 2(1), 1-22.

Ana Dili Eğitimi Dergisi
Journal of Mother Tongue Education
ADED - JOMTE
www.anadiliegitimi.com

\title{
Türkçe Deyimlerde Dil Farkındalığı ve İşlevsel Dil Kullanımı ${ }^{1}$
}

\author{
Bilginer Onan * \\ Hüseyin Özçakmak ${ }^{* *}$
}

\begin{abstract}
Özet
Bu çalışmada, Türk halk edebiyatı kültürünün anonim ürünlerinden biri olan deyimler, ana dili eğitimi çerçevesinde, dil farkındalığı ve işlevsel dil kullanımı yönünden analiz edilmiştir. Çalışmanın giriş bölümünde, deyimler hakkında kuramsal bir bilgi zemini oluşturulduktan sonra çalışmanın temel kavramları olan dil farkındalığı ve işlevsel dil kullanımı hakkında bilgi verilmiştir. Çalışmanın birinci bölümünde, deyimlerin temel dil becerileri açısından analizleri yer almaktadır. Bu bağlamda konuşma, dinleme, yazma ve okuma kavramlarıyla ilgili olan sözler, literatür tarama yöntemiyle 4 ayrı kaynaktan ayrı ayrı derlenmiş; yüzey yapı açısından benzer olanlar elenmiştir. Bu eleme sonucunda, sadece dil öğretiminde tanımlanan temel dil becerileriyle ilgili olan 526 adet deyim tespit edilmiştir. Ardından, dille ilgili olan deyimler konuşma, dinleme, okuma ve yazma öğrenme alanlarına göre ayrı ayrı tasnif edilmiş ve bu tasnifler çerçevesinde analizleri yapılmıştır. Analizler sonucunda elde edilen veriler tablolaştırılıp yorumlanmıştır. Çalışmanın sonucunda dille ilgili olduğu tespit edilen 526 adet deyimin \%80.42'sinin (423 adet) konuşmayla, \%10.84'ünün (57 adet) dinlemeyle, \%7.22'sinin (38 adet) yazmayla ve \%1.52'sinin (8 adet) okumayla ilgili olduğu tespit edilmiştir. Bu deyimlerin önemli bir bölümünde dilin davranış yönüyle ilgili bilimsel terminolojiye yansımamış durumların ayrıntılı bir şekilde terimleştirildiği görülmüştür. Deyimler, dilin davranış yönüyle ilgili ayrıntılı durumları sözlü ve yazılı dilde terimleştirme özelliğine sahiptir. Bu örneklerin özellikle sözlü dilde ağırlıklı olarak kullanılması bireyin işlevsel dil kullanma becerisini geliştirmesi bakımından son derece önemlidir.
\end{abstract}

Anahtar Kelimeler: Deyim, İşlevsel Dil Kullanımı, Dil Farkındalığı, Ana Dili Eğitimi

\section{Language Awareness and Functional Language Use in Turkish Idioms}

\begin{abstract}
This study analyzes idioms which are anonymous cultural elements of Turkish folk literature in terms of language awareness and functional language use within the framework of mother language education. In introduction part, a theoretical information background is granted on idioms and then language awareness and functional language use which are main concepts of the study are elaborated. In the first chapter, idioms are analyzed in terms of basic language skills. In this scope, idioms related to speaking, listening, writing and reading concepts are collected from 5 different sources; those having the similar structure are eliminated. In the end, 526 idioms which are defined only in language education related to basic language skills are detected. Afterwards, idioms related to language are classified by learning domains of speaking, listening, reading and writing and analyses are conducted within the framework of this classification. The obtained data are presented in tables and interpreted. It is found, in 526 idioms $80.42 \%$ (423) are related to speaking; $10.84 \%$ (57) are related to listening, $7.22 \%$ (38) are related to writing and $1.52 \%(8)$ are related to reading. It is seen that in most of these idioms,
\end{abstract}

\footnotetext{
${ }^{1}$ VI. Uluslararası Dünya Dili Türkçe Sempozyumu'nda (4-7 Aralık 2013, Bursa) bildiri olarak sunulmuştur.

* Doç. Dr., Mustafa Kemal Üniversitesi Eğitim Fakültesi Türkçe Eğitimi Bölümü, Hatay.

E-posta: bilgineronan@gmail.com

${ }^{* *}$ Arş. Gör., Mustafa Kemal Üniversitesi Eğitim Fakültesi Türkçe Eğitimi Bölümü, Hatay.

E-posta: h.ozcakmak@hotmail.com
} 
incidents that do not take place in scientific terminology of behavioral language are included in a more detailed individual terminology. Idioms can term detailed incidents related to behavioral language within verbal and written language. The use of these examples especially in verbal language majorly is very important for the development of language use skill.

Key Words: Idiom, Functional Language Use, Language Awareness, Mother Language Education

\section{Giriş}

Yüzyıllar öncesinden günümüze kadar ulaşmış halk edebiyatı ürünlerinin en önemli dil malzemelerinden biri de deyimlerdir. Bugün, Türkçedeki deyimlerin sayısı, henüz tam olarak bilinmemektedir. Ancak tespit edilen örneklerden yola çıkarak Türkçenin deyimler yönünden oldukça zengin bir dil olduğunu söylemek mümkündür. Tespit edilen deyim örneklerinden hareketle farklı kaynaklarda deyimlerle ilgili şu açıklamalara yer verilmiştir.

Deyimler, sözlük anlamıyla gerçek anlamından az çok ayrı, ilgi çekici anlam taşıyan kalıplaşmış söz öbekleridir (TDK, 2005: 517). Saraçbaşı ve Minnetoğlu'ya (2002: 7) göre deyimler kalıplaşmış sözlerdir. Donmuş, kemikleşmiş hâldedirler. Sözcüklerinde meydana gelebilecek en küçük bir değişiklik bile manalarını değiştirir. Kısa ve özlüdürler. En az iki sözcükle kurulurlar. Çoğunlukla mastar halindedirler, fiil çekimine girebilirler. Deyimlerin çoğunda kalıplaşmış sözden çıkan anlam, sözcüklerin gerçek anlamından başkadır. Bazı deyimlerde ise anlam, kelimelerin gerçek anlamına uygundur. Bir dua ya da ilençteki kalıplaşmış söz topluluğu, onun deyim sayılmasına elverişli bir anlatım güzelliği ve çekiciliği taşıyorsa deyim sayılabilir. Allah gecinden versin, Adı batasıca örneklerinde olduğu gibi. Kimi deyimlerin doğuş nedenleri, bir olay ya da hikâyeye dayanmaktadır.

Aksoy, deyimleri biçim ve kavram özelliklerine göre değerlendirmiştir. Biçimsel özellikleriyle ilgili şu bilgilere yer vermektedir: "Deyimler, kalıplaşmış sözlerdir. Atasözleri gibi kısa ve özlü anlatım araçlarıdır. En az iki sözcüğün bir araya gelmesiyle oluşmaktadırlar ve biçim olarak iki türe ayrılmaktadırlar. Birinci bölümü, sözcük öbeği durumundaki deyimler oluşturmaktadır. İkinci bölümü ise tümce durumundaki deyimler oluşturur. Kimi sözler, fiil çekiminin değişmesi ile atasözü iken deyim, deyim iken atasözü durumuna girebilir"(1995: 38-40). Aksoy, deyimlerin kavram özellikleriyle ilgili şu bilgilere yer vermektedir: "Deyim, bir kavramı belirtmek için bulunmuş özel bir anlatım kalıbıdır. Genel kural niteliğinde bir söz özelliği taşımaz. Deyimi atasözünden ayıran en önemli özellik budur. Deyimlerin amacı, bir kavramı ya özel bir kalıp içinde ya da çekici, hoş bir anlatımla belirtmektir. Atasözlerinin amacı ise yol göstermek, ders ve öğüt vermek, ibret almamız için gerçekleri bildirmektir. Deyimler, kavramsal özellikleri bakımından de iki grupta incelenmektedir. Birinci grubu oluşturan deyimlerde kalıplaşmış sözden çıkan anlam, sözcüklerin gerçek anlamının dışındadır. İkinci grubu oluşturan deyimlerde ise kalıplaşmış sözden çıkan anlam, sözcüklerin gerçek anlamları dışında değildir" (1995: 40-43). 
Sözlü dil ürünü olmaları sebebiyle deyimler konuşma dilinde sürekli işlendikleri için zaman içerisinde anlam ve özellikle de şekil yönünden farklı dil özelliklerine sahip olmuşlardır. Bu durum Elçin (2001: 642-644) tarafından şu şekilde dile getirilmektedir: "Deyimler, asıl anlamlarından uzaklaşarak yeni kavramlar meydana getiren kalıplaşmış sözlerdir. İki veya daha çok kelimeden kurulu bir çeşit dil ifadesi olan bu sözler, duygu ve düşüncelerimizi dikkat çekecek biçimde anlatan sıfat, zarf, basit ve birleşik fiil görünüşlü gramer unsurlarıdır. Birçoğu mastar hâlindedir. Her zamanlı fiil çekimleriyle kullanılabilirler. Deyimlerdeki bazı kelimeler isim ve fiil çekimlerine girebilirler. Kalıplaşma sebebiyle fiil çekimine girmeyen az sayıda deyim vardır. Hiçbir fiil kipi taşımadığı için cümle hâlinde bulunmayan deyimler de vardır. Bazıları iyelik ekleri ile kurulurlar. Aynı kelimenin tekrarı ile yapılan ikizleme deyimler vardır (günü güne, kaçan kaçana, boşu boşuna). Kafiyeli deyimler de vardır. Deyimlerde olumsuz kavram içeren kalıplar da kullanılmaktadır. Deyimler, soyut kavramları açıklamak için somut kavramlara başvururlar. Deyimlerdeki hayaller çok defa mantık dışı veya mübalağalıdır. Türk dilindeki deyimleri a. Umumî olanlar b. Bölge karakteri gösterenler c. Türkiye dışındaki Türk lehçelerinde yaşayanlar ç. Eskiden kullanılıp bugün unutulanlar olmak üzere dört ana grupta toplamak mümkündür."

Bir ulusun düşünüş tarzını, kozmoloji denilen evren algısını belirlemede deyimler araştırmacılara önemli ipuçları sunmaktadır. Deyimlerin bu işlevlerini Aksan (1999: 91) şu şekilde izah etmektedir: "Deyimler bir başka ulusla olan kültür ilişkileri sonunda, ondan çevrilme, alınma değilse bir dili konuşan toplumun dünya görüşünü, yaşam biçimini, çevre koşullarını, gelenek, görenek ve inançlarını, önem verdiği varlık ve kavramları, kısaca maddi ve manevi kültürünü yansıtan, o toplumun düşünme biçimini, hatta nükteli buluşlarını ortaya koyan, dilbilim açısından olduğu kadar yazın ve halk bilim açısından da önemli olan sözlerdir. Ayrıca bu öğeler her dilin içyapısını, anlam özelliklerini de yansıtır. Bu nitelikleriyle deyimler, her dilin kendine özgü, başkalarından ayıran bir yönünü oluşturmaktadır. Bir dilin gerçekleri dile getirmedeki anlayış ve anlatış biçimini göstermektedir. Dilciler ve halkbilimciler, sadece deyimlere dayanarak bir toplumun bütün kültürünü inceleyebilirler, önemli sonuçlar çıkarabilirler."

Deyimlerin anlam ve biçim özellikleriyle ilgili verilen bu bilgilerin ardından, çalışmanın temel noktalarından biri olan dil farkındalığı kavramı üzerinde durmak gerekiyor. "Dil farkındalığı (language awareness) terimi ilk kez 1984'te araştırma özetlerini yayınlayan ve uluslararası indekslerden biri olan Language Teaching dergisinde yer almış, yine aynı yıl Eric Hawkins tarafından yazılan Awareness of Language: An Introduction başlıklı kitapta incelenmiştir. Kavram, 1992'de Bangor'da yapılan ilk Uluslararası Dil Farkındalığı konferansında ayrıntılı olarak ele alınmış, bu konferansta kurulması kararlaştırılan derneğin çalışmaları ile önem kazanarak daha sonraki yıllarda değişik disiplinlerin de inceleme konuları içine girmiştir. Dil farkındalığı terimi, bireyin kendi dilinin özelliklerine ve kullanımına karşı geliştirdiği bilinç ve duyarlılık anlamında kullanılmış, bu bilinç ve duyarlılığın etkili 
eğitim süreçleri ile kazandırılabileceği düşünülmüştür (Büyükkantarcıoğlu, 2006: 103). Bir başka açıdan dil farkındalığı "bireyin kendi sözlü ve yazılı dil kullanımını da denetleyebileceği bir biçimde sözcük seçiminden biçimbirimsel, sözdizimsel ve anlamsal yapı doğruluğuna, yazım ve noktalama kurallarından düşünce düzenleme ve aktarma becerisine kadar ana dilin doğru ve etkin kullanımına yönelik geliştirdiği bilinçli bir dil kullanım duyarlılı̆ıdır" (Büyükkantarcıoğlu, 2003: 20). Bireyde dil kullanımına yönelik duyarlılı̆ın oluşumu okul öncesi dönemin başlangıcına kadar uzanmaktadır. "Dili kullanma yetisiyle doğan çocuk, sosyal çevrede ana diline ait ilk bilgileri edinmeye başlamaktadır. Çocuğun formal eğitim sürecine kadar edindiği bu bilgilere örtük bilgi adı verilmektedir. Formal eğitimin başlamasıyla birlikte bu örtük bilgiler açık bilgiye dönüştürülmektedir. Dil farkındalığının oluşabilmesi için açık bilgilerin tekrar örtük bilgiye dönüştürülmesi gerekmektedir. Açık bilgiden örtük bilgiye geçiş, ana dili öğretiminde dil kullanımının davranışa dönüştüğünün göstergesidir" (Onan, 2011: 92).

Dil farkındalığı ile birlikte ele alınan işlevsel dil kullanımı ise "içinde bulunduğu toplumun yazıı ve sözlü dil ölçütlerine ve beklentilerine koşut olarak, bireyin iletişimsel amaçlarının etkin olarak gerçekleştirilmesi, kendisinin ve toplumun gelişmesine katkıda bulunması ve bireyden beklentileri giderek artan bir dünyada kendisini ana dilinin okuma / anlama, dinleme / anlama, yazma ve konuşma becerilerinde yetkin kılması biçiminde tanımlanmaktadır" (Büyükkantarcıoğlu, 2003: 22). Dil farkındalığı ve işlevsel dil kullanımı birbiriyle ilişkili kavramlardır.

Doğum öncesinden itibaren içinde yaşadığı toplumsal çevrenin dilini ve kültürünü örtük olarak kazanmaya başlayan birey, kendi halk kültürüne ait deyimlerle ilk kez dinleme yoluyla karşılaşır. Örtük bilginin açık bilgiye dönüştürüldüğü süreçte deyimlerle ifade edilen dil kullanımına ait nüansları kelime hazinesine dâhil eder. Çocukların okul öncesi dönemde dinleme yoluyla kazandıkları bu kullanımların kalıcı olabilmesi için örgün eğitim sürecinde desteklenmesi gerekmektedir. Bu süreçte öğretmenlerin ve ders kitaplarının önemli bir işlevi vardır. Deyimlerin dil farkındalığını geliştirmedeki işlevleri bu noktada devreye girmektedir. Bunları şu şekilde izah etmek mümkündür:

Deyimler, dil farkındalı̆ını kazandırmada soyut kavramlardan hareket etmektedir. Soyut kavramları temsil eden ve çoğu aktarmalar yoluyla oluşmuş örtülü anlam taşıyan bu yapılar âdeta temel dil becerilerinin kavram alanlarını oluşturmaktadır. Bunun yanı sıra deyimler, temel dil becerilerinin kullanım katmanlarını terimleştirme işlevine de sahiptir. Bu terimler belirli bir bilim alanına ait olmayıp halkın dilinde sürekli olarak kullanılan ifadelerdir. Bu açıdan bakıldığında deyimler, dilin davranış yönünü temsil eden durumları, bilimsel terminolojinin dışında ikinci bir dil oluşturarak kodlamaktadırlar. Dilin davranış yönüyle ilgili bazı durumların deyimsel ifade dışında kullanımları yoktur. Aktarma yoluyla oluşan bu terimler, aynı zamanda dilin içinde yaşadığı çevreyi de sözcelem ortamına dâhil etmektedir. 
Sonuç olarak, temel dil becerilerinin sözcelem ortamındaki manalarının tespiti noktasında deyimler potansiyel kavramlar olarak düşünülmelidir. Deyimlerdeki bu potansiyelin belirlenmesi ve dil eğitimi açısından kelime hazinesi içindeki değerlerinin ortaya çıkarılması çalışmanın hareket noktasını oluşturmaktadır. Deyimlerin bu süreçteki işlevlerini tespit edebilmek için öncelikle temel dil becerilerinin kavram alanlarıyla ilgili örneklerin belirlenip dilin davranış yönünü oluşturan kavramlar çerçevesinde analiz edilmesi gerekmektedir.

\section{Yöntem}

\section{Araştırma Modeli}

Türkçe deyimlerde dil farkındalığı ve işlevsel dil kullanımını değerlendirmeyi amaçlayan bu araştırma, nitel veri toplama ve çözümleme tekniklerinden yararlanılarak gerçekleştirilen betimsel tarama modelinde bir araştırmadır. Tarama modelleri, geçmişte ya da halen var olan bir durumu var olduğu şekliyle betimlemeyi amaçlayan araştırma modelleridir (Karasar, 2009: 77-79).

\section{Çalışma Materyali}

Çalışma materyali, deyim sözlükleri arasından 4 sözlüğün amaçlı örnekleme yöntemi ile seçilmesi ile oluşturulmuştur. "Amaçlı örnekleme, olasılı ve seçkisiz olmayan bir örnekleme yaklaşımıdır. Amaçı örnekleme çalışmanın amacına bağlı olarak bilgi açısından zengin durumların seçilerek derinlemesine araştırma yapılmasına olanak tanır." (Büyüköztürk, Kılıç Çakmak, Akgün, Karadeniz ve Demirel, 2008: 78).

Çalışmada kullanılan kaynaklar ise şu şekildedir:

Tablo 1: Çalışmada Kullanılan Kaynaklar

\begin{tabular}{cll}
\hline & Kaynak Adı & Yazar Adı \\
\hline 1 & Atasözleri ve Deyimler Sözlüğü I, II & Ömer Asım Aksoy \\
2 & Türk Atasözleri ve Deyimleri II & Millî Eğitim Bakanlığı \\
3 & Örnekli ve Açıklamalı Türkçe Deyimler Sözlüğü & M. Ertuğrul Saraçbaşı ve İbrahim Minnetoğlu \\
4 & Sınıflandırılmış Deyimler Sözlüğü & Metin Yurtbaşı \\
\hline
\end{tabular}

\section{Verilerin Toplanması}

Çalışmada kullanılan veriler, üç aşamada toplanmıştır. Birinci aşamada okuma, yazma, konuşma ve dinleme becerileri ile ilgili olan deyimler her bir sözlük için ayrı ayrı tespit edilmiş, tespit edilen deyimler 4 farklı Excel dosyasında kodlanmıştır. İkinci aşamada, bu 4 dosya birleştirilmiş, birbirinin aynısı olan deyimler listeden çıkarılarak tek bir dosya oluşturulmuştur. Üçüncü aşamada ise kodlamaların güvenirliğini sağlamak üzere, birinci araştırmacı tarafından belirlenen deyimler, ikinci araştırmacı tarafından kontrol edilmiştir. Yapılan kontroller sonrasında veri kodlamaları üzerinde büyük oranda görüş birliği sağlandığı görülmüş, görüş birliğine varılamayan kodlamalar ise iptal edilerek dil becerileri ile ilgili veri havuzuna son şekli verilmiştir. 


\section{Verilerin Analizi}

Deyimlerin analizi iki aşamalı olarak gerçekleştirilmiştir. Illk aşama; okuma, yazma, konuşma ve dinleme becerileri ile ilgili deyimlerin tespit edilmesi aşamasıdır. Bu aşamada tek bir havuzda birleştirilmiş olan deyimler, araştırmacılar tarafından üzerinde görüş birliği sağlanarak okuma, yazma, konuşma ve dinleme başlıkları altında toplanmış ve bulgular kısmında tablolaştırılmıştır. Íkinci aşamada ise okuma, yazma, konuşma ve dinleme başlıkları altında toplanan deyimlerin derin ve yüzey yapı durumları ele alınmıştır. Bu aşamada okuma, yazma, konuşma ve dinleme ile ilgili deyimlerin derin ve yüzey yapı sayıları tespit edilmiş, derin yapılarının kaç yüzey yapıyla temsil edildiği belirlenmiştir.

\section{Bulgular}

Bu bölümde, deyimlerin temel dil becerilerine göre dağılımları ile yüzey yapı-derin yapı durumları ele alınacaktır.

\section{Dille İlgili Deyimlerin Temel Dil Becerilerine Göre Dağılım Oranları}

Taranan kaynaklardan elde edilen ve dil becerilerine göre tasnif edilen deyimlerin dağılım oranları aşağıdaki tabloda verilmiştir.

Tablo 2: Dille Ilgili Deyimlerin Temel Dil Becerilerine Göre Dağılım Oranları

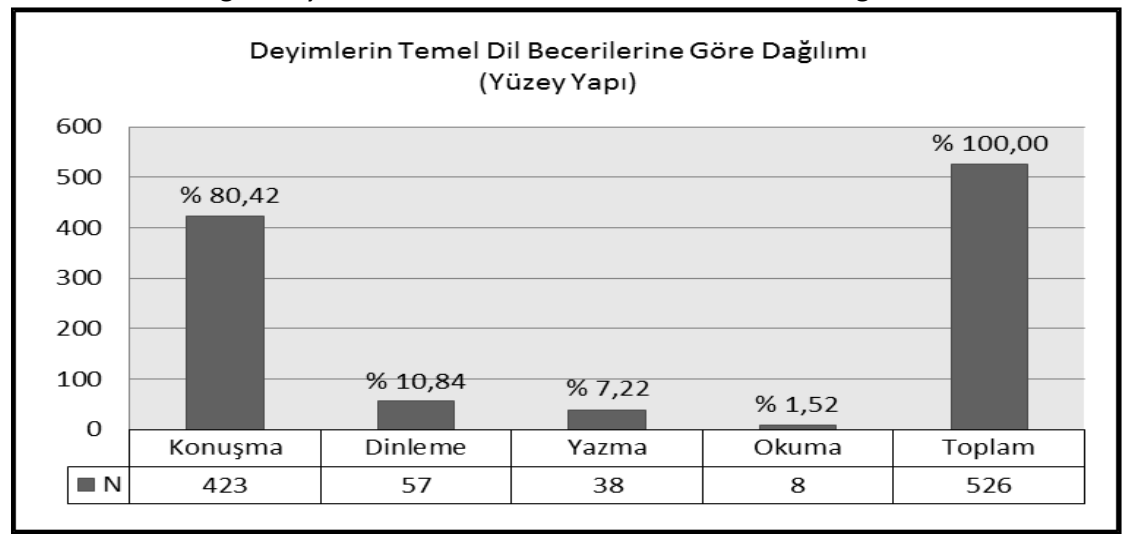

Tablo 2'de, kaynaklardan taranarak tespit edilen ve dil becerileri ile ilgili olan 526 adet deyim yer almaktadır. Deyimlerin temel dil becerilerine göre dağılım oranlarında ağırlığın konuşma becerisi üzerinde olduğu görülmektedir.

Çalışmada, konuşma becerisiyle ilgili 423 deyim tespit edilmiştir. Tablo 2'deki dağıııma göre dille ilgili deyimlerin genel toplamının \%80.42'sini konuşma becerisiyle ilgili deyimler oluşturmaktadır. İkinci sırada, 57 adet deyimle dinleme becerisi gelmektedir. Genel toplamın \%10.84'ünü dinleme becerisiyle ilgili deyimler oluşturmaktadır. Üçüncü sırada 38 adet deyimle yazma becerisi yer almaktadır. Genel toplamın \%7.22'sini yazma becerisiyle ilgili deyimler oluşturmaktadır. Dördüncü ve son sırada 8 adet deyimle okuma becerisi gelmektedir. Genel toplamın \%1.52'sini ise okuma 
becerisiyle ilgili deyimler oluşturmaktadır. Görüldüğü gibi, dille ilgili deyimlerde konuşma becerisi ön plana çıkmaktadır. Bu durum kuşkusuz, deyimlerin sözlü kültür ürünü olmalarından kaynaklanmaktadır.

Temel dil becerileri ile ilgili deyimlerin derin yapıları incelendiğinde ise karşımıza şöyle bir tablo çıkmaktadır:

Tablo 3: Derin Yapıların Temel Dil Becerilerine Göre Dağılım Oranları

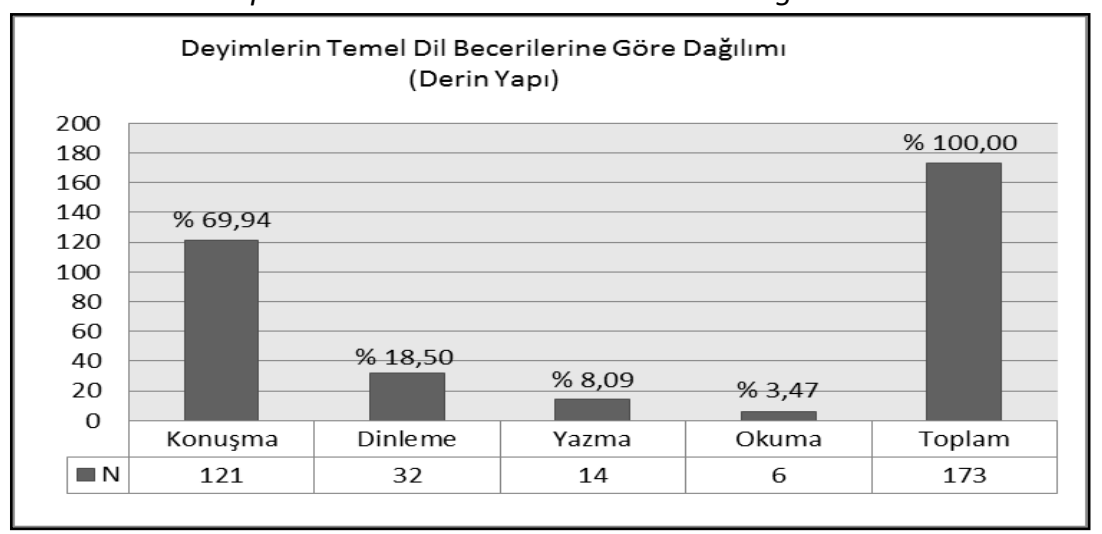

Konuşma, dinleme, yazma ve okuma becerileriyle ilgili deyimlerde tematik anlam taşıyan derin yapıların farklı yüzey yapılarla dile getirildiği görülmektedir. Deyimlerdeki yüzey yapılarla karşılaştırıldığında derin yapıların oldukça sınırlı kaldığı görülmektedir. "Benzer durum dille ilgili olan atasözlerinde de tespit edilmiştir" (Onan, 2011: 94). Dille ilgili deyimlerdeki derin ve yüzey yapılar incelendiğinde dilin davranış katmanlarını karşılayan bir ifade zenginliği göze çarpmaktadır. Bu zenginlik, temel dil becerilerine ait deyimlerin analiziyle daha da açık bir şekilde ortaya konacaktır.

\section{Konuşma Becerisi ile İlgili Deyimlere Ait Bulgular ve Yorumlar}

Dille ilgili deyimler içerisinde, konuşma becerisi ile ilgili olanlar yukarıdaki tablodan da anlaşılacağı gibi genel toplamın \%80.42'sini (423 adet) oluşturmaktadır. Konuşma eğitimiyle ilgili terminoloji incelendiğinde, bu kavramla ilgili deyimlerin dil farkındalığı yönünden ne denli zengin olduğu görülecektir. Konuşma becerisi, dilin davranış katmanlarını ifade eden kavram alanı yönünden en zengin deyim grubuna sahiptir. Çalışmada konuşma kavram alanıyla ilgili tespit edilen 423 adet deyim, içerdikleri derin yapılar yönünden analiz edilmiş, bu temel beceriye ait 121 derin yapı belirlenmiştir. Konuşma ile ilgili derin yapılar genel toplamın \%69.94'ünü temsil etmektedir. Bu derin yapılar, konuşma becerisi ile ilgili 121 farklı davranış katmanıyla ilgilidir ve konuşma becerisindeki dil farkındalığı seviyesini göstermektedir. Bu derin yapılar aynı zamanda dil eğitiminde son derece önemli bir yere sahip olan konuşma eğitiminin davranış yönünün sosyokültürel tabanını oluşturmaktadır. Bu taban, deyimler yoluyla terimleşerek nesilden nesile aktarılagelmiştir. 
Konuşma becerisinin davranış katmanlarını oluşturan derin yapılar aşağıda sıralanmıştır:

Aniden konuşmaya başlamak, anlamsız yere konuşmak, aslı olmayan bir şey için yemin etmek, az konuşmak, belirli bir konuya odaklanmadan konuşmak, belirli bir kimseyi hedef almadan konuşmak, bilgi sahibi olunmayan konularda konuşmak, farkında olmadan bir anda söyleyivermek, bir bilginin kişiden kişiye aktarılması, bir kişi veya konu hakkında ağzına geleni söylemek, bir kişiyi sözle ikna etmeye çalışmak, karşısındaki kişiyi konuşturmamak, bir kişiyi sözle kandırmak, bir konu hakkındaki düşüncelerini sıralamak, bir konuyla ilgili aynı düşünceleri dile getirmek, bir konuyu sık sık dile getirmek, bir konuda konuşmaya yetkili olmak, bir konuda savunduğu fikri daha sonra değiştirmek, verdiği sözü yerine getirmemek, bir konunun herkes tarafından konuşulması, bir konuya az değinmek (hatırlatmak) az bilgi vermek, kesin karar almak, bir konu hakkında konuşmaya başlamak, vaatte bulunmak, sorulan bir soruya cevap verememe, bir sözü tam yerinde ve zamanında söylemek, bir şeyi söylemek üzere olmak, bir şeyi tam olarak söyleyememek, bir işin ne kadar zor olduğu, topluluk karşısında konuşmak, konuşmamak, bir kişiden diğerine söz taşımak, birinin ağzından laf almaya çalışmak, bir kişiden bahsederken özen göstermek, bir kişiye dokunacak sözü ortaya söylermiş gibi yapmak, bir kişi için konuşma fırsatı yaratmak, bir kişiye kötü söz söylemek, sert bir şekilde sözle uyarmak, sözle ikna etmek, çok konuşulan bir ortamda rahatsız olmak, biri veya birilerinin arkasından konuşmak, kötü bir sözün kişi üzerindeki olumsuz etkisini ifade ederken, birinin sözlerine anında karşılık vermek, birinin konuşmasına müdahale etmek, önemli bilgiler veren insanlar için, birinin sözünün geçerli olduğu durumları ifade etmek için, bir kişiyle çok konuşma yarışına girmeyi ifade ederken, bir şeyin kusursuz olduğunu ifade ederken, boş konuşanlarla alay etmek, cesaretli bir şekilde konuşma, cevap verme, bir kişinin ne kadar çok konuştuğunu ifade ederken, alçak sesle konuşmak, derdini bir başka kişiye anlatmak, dikkatsiz bir şekilde konuşmak, düşünerek dikkatli bir şekilde konuşmak, gaf yapmak, gelip geçici önemsiz konulardan bahsetmek, gerçekleri olduğu gibi söylemek, karşıııkı olarak güzel konulardan konuşmak, güzel konuşan insanlar için, güzel konuşayım derken işleri berbat etmek, haddini bilerek konuşmak, hatalı sözler söylemek, hazır cevap olmak, bir kişinin her isteğinin yerine gelmesi, bir kişinin her konuyla ilgili sözler söyleyebilmesi, her şeyi her yerde söylemek, herkesin aynı anda konuşması, herkesle iletişim kurabilmek, herkesin isteğine göre konuşabilmek, her şeye rağmen bir sırrı ortaya çıkarmamak, konuşma becerisinin gelişmiş insanlar için, ilgi çekici konuşma yapan bir kişi için, inandırıcı olmayan oyalayıcı sözler söylemek, isteksiz bir şekilde konuşmak, bir konunun en önemli kısmından söz etmek, karşı çıkmak, söylediği sözlerle kendini ele vermek, konuşmamak, konuşarak bir kişiyi meşgul etmek, şiddetli bir şekilde tartışmak, bir kişinin konuşma hakkının olmadığı, konuşmak için izin istemek, konuşmanın satır aralarında geçenler için, konuşmasının sakıncalı bir durum aldığını anlayınca başka bir konuya yönelmeyi ifade etmek için, konuşmaktan çekinme, küçücük bir konuyu büyütüp kavga çıkarma, her şeyi ayrıntısıyla anlatma, örtülü konuşma, bir konuşmayı sonuca bağlama, özür dileyerek söylediklerinden vazgeçme, sabır 
gösterip konuşmama, selâm söylemek, sır tutamamak, sır tutmak, karşısındaki kişiye öfkeli bir şekilde cevap vermek, söylediği sözlerden ötürü kötü duruma düşmek, sözler ile davranışların tutarlı olması, söylediği sözleri her durumda haklı bulma, söylediklerinin arkasında olma, bir türlü söylemek istediği asıl konuya gelememe, sözlerinin o topluluktaki kişileri ilgilendirmediğini vurgulamak istediği zaman, söz söylemek, sözle şaka yapmak, bir kişinin sözlerinin anlaşılmaması, önemsenmemesi, sözlerinin doğru olduğuna inanmaları için insanları zorlamak, sözü gereksiz yere uzatmak, sözün değerinin kalmadığını ifade etmek için, sürekli olarak birinin dilinde olmak, sürekli olarak soru sormak, şive / ağız özelliği göstererek konuşmak, tutarsız konuşan insanlar için, yalvarmak, yanlış telaffuz etmek, yanlışı ve doğruyu bir arada söylemek, yapıcı bir şekilde konuşmak, yardım çağırmak, yerine getiremeyeceği türden sözler söylemek, yüksek sesle konuşmak.

Konuşma becerisiyle ilgili deyimlerin derin ve yüzey yapıları karşılaştırıldı̆̆ında yüzey yapıların derin yapılara oranla oldukça fazla olduğu görülmektedir. Konuşma becerisiyle ilgili deyimlerde derin yapı ve yüzey yapı oranlarında \%-71.39 oranında bir değişim söz konusudur.

\section{Tablo 4: Konuşma Becerisiyle Ilgili Deyimlerde Yüzey Yapı-Derin Yapı Oranları}

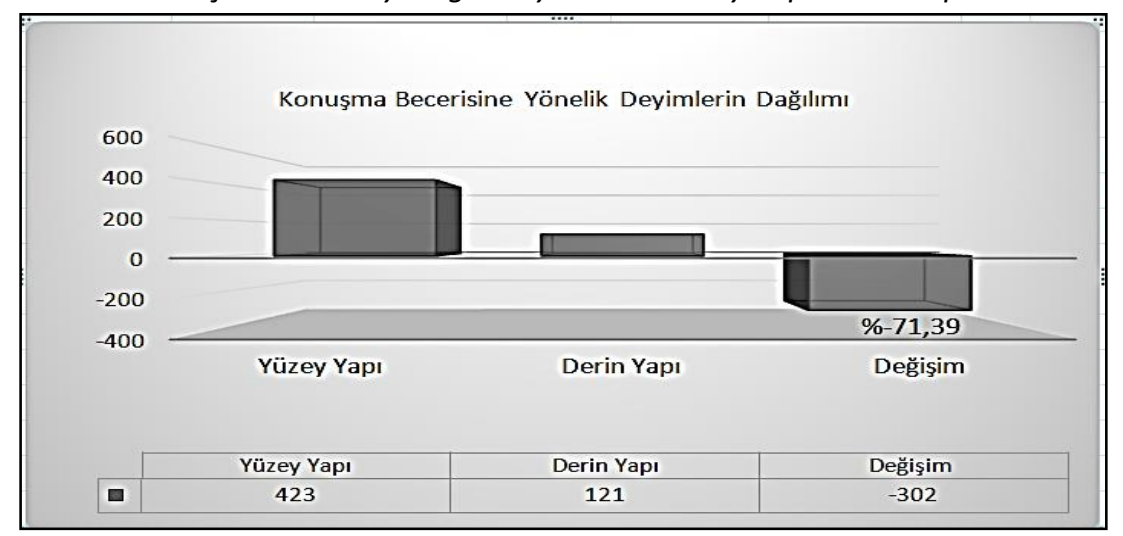

Konuşma becerisinin kavram alanını tasnif eden bu derin yapılarda, ilköğretim birinci ve ikinci kademede verilen konuşma eğitiminde öğrencilere kazandırılması gereken bütün davranış katmanlarının yer aldığı, hatta bilimsel literatürde değinilmeyen konuların deyimler yoluyla sözlü dil ortamında yer aldığı görülmektedir. Konuşmanın davranış yönüyle ilgili hususların önemli bir bölümü konuşma eğitimiyle ilgili bilimsel literatürde uzun açıklamalar ve tanımlar çerçevesinde yer almaktadır. Oysa deyimler, bu uzun açıklama ve tanımları adeta terimleştirmiş ve sözcelem ortamında sıkça kullanılır hâle getirmiştir. Konuşmanın kavram alanında yer alan deyimler, konuşma eğitimiyle gündelik dil kullanımı arasındaki boşlukları doldurmaktadır. Aşağıda verilen örnekler bu durumu somutlaştırıyor.

Çenesi düşük olmak: Sözlü dilde çok konuşan insanlar için kullanılan bir deyimdir ve çenesi düşük bir kişi, bulunduğu ortamdaki diğer insanları rahatsız etmektedir. Bu durum konuşma eğitimi ile ilgili kaynaklarda da geçmektedir. Bulunduğu ortamdaki insanları konuşarak rahatsız etme durumu sözlü dilde çenesi düşük deyimiyle terimleşmiştir. Türkçede, aynı durumu terimleştiren ağız 
açtırmamak, çan çan etmek, çenesi kuvvetli olmak, dil otu yemiş, kulağından gebe etmek, gem almamak, car car etmek, söz ebesi gibi kullanımlar da mevcuttur. Bunlara yenileri eklenebilir.

Baltayı taşa vurmak: Söylenmemesi gereken bir şeyi farkında olmadan söyleyerek karşısındaki kişi veya kişileri rahatsız etmek anlamında kullanılmaktadır. Konuşma eğitiminin en önemli davranış katmanlarından birini oluşturan bu durum dilimizde baltayı taşa vurmak, gaf yapmak, çam devirmek, boş bulunmak, pot kırmak, şom ağızlı olmak vd. deyimlerle de dile getirilmektedir.

Ağzından bal akmak / damlamak: Güzel konuşan, karşısındaki insanları sözleriyle bilgilendiren ve rahatlatan insanlar için kullanılan bir deyimdir. İletişim açısından son derece önemli olan bu durum ağzından bal akmak, ağzından bal damlamak, ağzını hayra açmak, söz ehli olmak, ağzını öpmek, sohbetine doyum olmamak, tatlı dilli olmak, diline şeker ezmek, gönül okşamak, hasbihal etmek vd. deyimlerle dile getirilmektedir. Benzer derin yapı özelliği gösteren bu deyimler arasında bile kullanıldıkları bağlama göre farkı anlam ayrıntıları ortaya çıkabilmektedir.

Dili tutulmak: Bir kişi, olay veya durum karşısında söz eyleminin ortadan kalkması ve susma durumunu ifade eden bir deyimdir. Konuşma becerisi ile ilgili deyimler analiz edildiğinde Türkçede en fazla bu derin yapı etrafında deyimlerin kümelendiği tespit edilmiştir. "Türkiye Türkçesi'ndeki konuşma kavramıyla ilgili atasözlerinde de aynı durum söz konusudur" (Onan, 2011: 95). Dilini kedi yemek, dilini kesip oturmak, dilini tutmak, dilini yutmak, ağzını açmamak, ağzını bağlamak, ağzını bıçak açmamak, çeneleri kilitlenmek, çenesini bıçak açmamak, çenesini tutmak, dut yemiş bülbüle dönmek, çıt çıkarmamak, put kesilmek, sus pus olmak, süt dökmüş kedi gibi olmak, taş kesilmek, tek kelime etmemek vb. deyimler bunların bir kısmını oluşturmaktadır.

Ağzı kara olmak: Kötü söz söylemek, sözleriyle bir kişinin kalbini kırmak anlamında kullanılan bir deyimdir. Bu tanım, ağzını bozmak, demir yalayıp ateş püskürmek, dili uzun olmak, dili zifir olmak, ağzı bozuk olmak, karış karış dili olmak vb. deyimlerle de dile getirilmektedir.

Konuşma becerisiyle ilgili deyimlerde uzak bağdaştırma nitelikli metaforik kullanımların yaygın olduğu görülmektedir. Bu durum deyimlerin kalıcılığını artırmaktadır. "Reynolds ve Schwartz'ın yaptıkları araştırmalar, metaforların öğrenme sürecindeki olumlu etkilerini ortaya koymaktadır. Bu iki araştırmacı, metaforların yeniden üretim sürecini daha kolay başlattığı ve daha uzun sürmesini sağladığı sonucuna ulaşmışlardır. Paivio, metafor özelliği taşıyan dil yapılarının etkililiğini ikili kodlama sistemi çerçevesinde açıklamıştır. Araştırmacı, deneysel ve teorik çalışmalara dayanarak metaforların oluşturulmasında ve anlaşılmasında özerk bir işleyiş̧e sahip olan ama karşılıklı bilgi alışverişinde bulunabilen iki sistemin rol oynadığını ileri sürmektedir. Biri dilsel bilgilerle ilgilidir ve sözel temsillerden yararlanır, bunları ardışık bir biçimde işlemden geçirir. Diğer sistem, somut nesne ve olaylarla ilgili bilgileri işlemden geçirir ve çoğunlukla görsel bir doğaya sahip olan imgelerde temsil edilir. Metaforlar, bu iki sistemin ortak çalışmasının ürünüdürler" (Draaısma, 2007: 37-38). Deyimlerin 
metafor özelliği taşımaları, sözlü dilin ürünü olmaları ve gündelik hayatın içinden görsel imgelerle temsil edilmeleri kullanım sıklığını ve kalıcılığı artırmaktadır. Dilin, özellikle de konuşmanın davranış yönüyle ilgili hususların kazandırılmasında deyimler, bu açıdan son derece önemli bir işleve sahiptir.

\section{Dinleme Becerisi ile Illgili Deyimlere Ait Bulgular ve Yorumlar}

Dille ilgili deyimler içerisinde, dinleme becerisi ile ilgili olanlar genel toplamın \%10.84'ünü (57 adet) oluşturmaktadır. Dinleme, dilin davranış katmanlarını ifade eden kavram alanı yönünden en zengin ikinci deyim grubuna sahip dil becerisidir. Çalışma kapsamında tespit edilen 57 adet dinleme kavram alanıyla ilgili deyim, içerdikleri derin yapılar yönünden analiz edildiğinde, bu temel beceriye ait 32 farklı derin yapı belirlenmiştir. Dinleme ile ilgili deyimlerin derin yapısı, genel toplamın \%18.50'sini oluşturmaktadır. Bu derin yapılar, konuşma becerisiyle ilgili 32 farklı davranış katmanını ifade etmektedir ve dinleme becerisindeki dil farkındalığı seviyesini göstermektedir. Bu deyimler aynı zamanda Türkçedeki dinleme kavramının sosyokültürel zeminini oluşturmaktadır.

Dinleme becerisinin davranış katmanlarını oluşturan derin yapılar aşağıda sıralanmıştır:

Aşırı sesten rahatsız olma, başkalarından duyulan ve güvenilir olmayan bilgiler için, başkasından aktarılan bilgiyi hemen anlamak, bilinçli bir şekilde birisini dinlememek, yapılan bir konuşmaya dikkat kesilmek, söylenen bir söz karşısındaki tahammülsüzlük, bir şeyi daha önce duymuş olmak, birinin söylediklerine önem vermek, bir şeyi dinlemek için dikkatini yönlendirmek, dinleyerek anlamak, eğlenerek dinlemek, bir şeyi herkesin duyduğunu ifade ederken, bir bilgiyi aklından hiç çıkarmamak, bir yerden haber bekleyen insanlar için, çok dikkatli bir şekilde dinlemek, dinleme sırasında dikkatin başka bir yerde olduğunu ifade ederken, bir bilgiyi belli belirsiz bir şekilde almak, bir konuyu anında anlamak, dinleyip de anlamamak, duyup da duymamazlıktan gelmek, pasif bir şekilde dinlemek, bir şeyi gizlice dinlemeye çalışmak, güzel bir müzik parçası dinlendiğinde, her şeyi bilen duyan insanlar için, işitme becerisinin çok az olduğu durumlarda, kötü söz duymak, ön yargıdan dolayı dinlememe, söylenen bir şeyi yanlış anlamak, söylenenin yerine getirilmesi için, sözle azarlanmak, terslenmek, uzun süre güzel şeyler dinlemeyen insanlar için, dinlerken sabırlı olmama.

Dinleme becerisiyle ilgili deyimlerin derin ve yüzey yapıları karşılaştırıldığında \%-43.86 oranında bir değişim olduğu görülmektedir. Konuşma becerisiyle kıyaslandığında dinleme alanındaki deyimlerde derin yapılar, daha az yüzey yapıyla temsil edilmektedir. Aşağıdaki tabloda bu durum görülmektedir. 
Tablo 5: Dinleme Becerisiyle IIgili Deyimlerde Yüzey Yapı-Derin Yapı Oranları

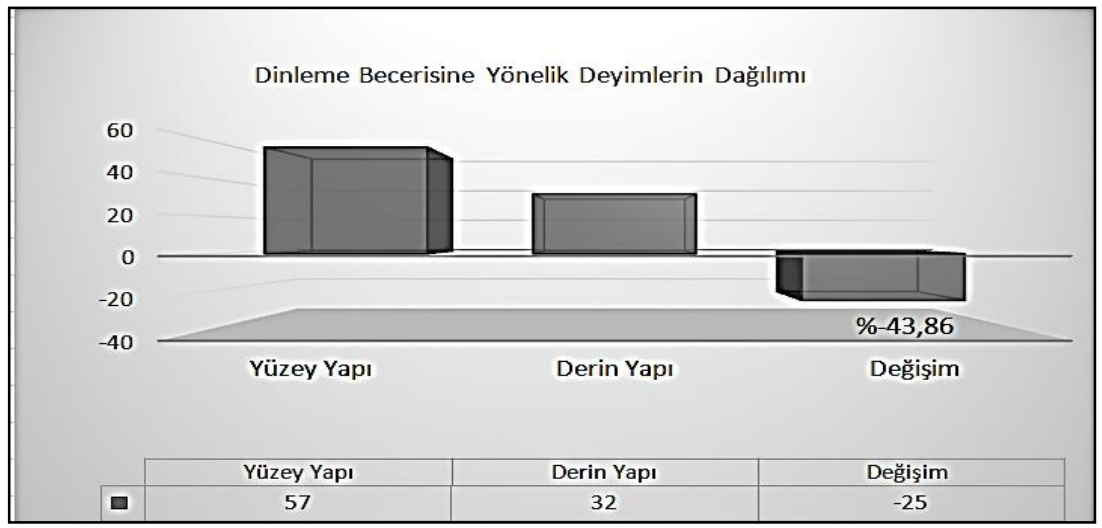

Konuşma becerisinin kavram alanına oranla sayıları daha az olmasına rağmen dinleme becerisinin kavram alanındaki deyimler de dinlemenin davranış katmanlarını temsil etmektedir. Deyim örnekleri incelendiğinde, dinleme eğitimiyle ilgili önemli hususların terimleştiği görülmektedir. Aşağıda verilen örnekler bu durumu somutlaştırmaktadır:

Kulaktan Dolma: Bu deyim, başkalarından duyulan ve güvenilir olmayan bilgiler için söylenmektedir. Dinleme anlama sürecinde kaynaktan gelen bilginin güvenilirliği son derece önemlidir. Alıcının yani dinleyicinin bu duruma dikkat etmesi gerekir. Kaynaktan gelen ve güvenilir olmayan bu bilgiler kulaktan dolma deyimiyle terimleşmiştir.

Kulak Kesilmek: Bir şeyi dinlemek için kişinin dikkatini yönlendirmesi ifade edilmektedir. Aynı durum Türkçede, kulağını dikmek, kulak kabartmak, kulak vermek, kulak tutmak gibi deyimlerle de dile getirilmektedir.

Kulak Dolgunluğu: Bir olayın, haberin, durumun daha önce duyulmuş olduğu ifade edilmek istendiğinde bu deyim kullanılmaktadır.

Kulak Ardı Etmek: Kaynaktan gelen bilgilerin alıcı (dinleyici) tarafından önemsenmediği durumlarda söylenmektedir. Türkçede kulak arkasına almak, kulak asmamak gibi deyimler de bu durumda söylenmektedir.

Dinleme becerisiyle ilgili deyimlerin konuşmaya göre dinleme literatüründe daha sınırlı bir alana yayıldığı görülmektedir. Bu açıdan bakıldığında, dinlemeyle ilgili deyimlerde dil eğitimiyle ilgili ayrıntılı bir terminolojiden söz etmek mümkün değildir.

\section{Yazma Becerisi ile ilgili Deyimlere Ait Bulgular ve Yorumlar}

Dille ilgili deyimler içerisinde yazma becerisi ile ilgili olanlar Tablo 2'de görüldüğü gibi genel toplamın \%7.22'sini (38 adet) oluşturmaktadır. Konuşma ve dinleme becerileriyle kıyaslandığında, yazma becerisine ait deyimlerin Türkçede oldukça sınırlı sayıda olduğu söylenebilir. Çalışmada tespit edilen 38 adet yazma becerisiyle ilgili deyim, içerdikleri derin yapılar yönünden analiz edildiğinde bu temel beceriye ait 14 derin yapı tespit edilmiştir. Yazma ile ilgili derin yapılar genel toplamın 
\%8.09'unu oluşturmaktadır. Bu derin yapılar, yazma becerisiyle ilgili deyimlerin dil farkındalık seviyesini göstermektedir.

Yazma becerisinin davranış katmanlarını oluşturan derin yapılar aşağıda sıralanmıştır:

Bilgisayar veya daktilo ile yazmak, birine ait olan bir yazı için, kaligrafik olarak kötü yazılmış anlaşılmaz yazılar için, kayıt altına almak, kötü şeyler yazanlar için, küçük ve anlaşılmaz harflerle yazılmış yazılar için, yazı yazamayan, yazı yazabilen kişileri tanımlarken, yazı yazmak, yazı yazmaya başlamak, yazı yazmayı iyi derecede bilen, yazı yazmayı öğrenmek, yazılanları daha itinalı bir şekilde yeniden yazmak, yazmada ön hazırlık niteliğinde taslak oluşturmak.

Yazma becerisiyle ilgili deyimlerin derin ve yüzey yapıları karşılaştırıldığında \%-63.16 oranında bir değişim olduğu görülmektedir. Konuşma ve dinleme becerisiyle kıyaslandığında yazma alanındaki deyimlerde derin yapılar, daha az yüzey yapıyla temsil edilmektedir. Tablo $6^{\prime}$ da bu durum görülmektedir.

Tablo 6: Yazma Becerisiyle ilgili Deyimlerde Yüzey Yapı-Derin Yapı Oranları

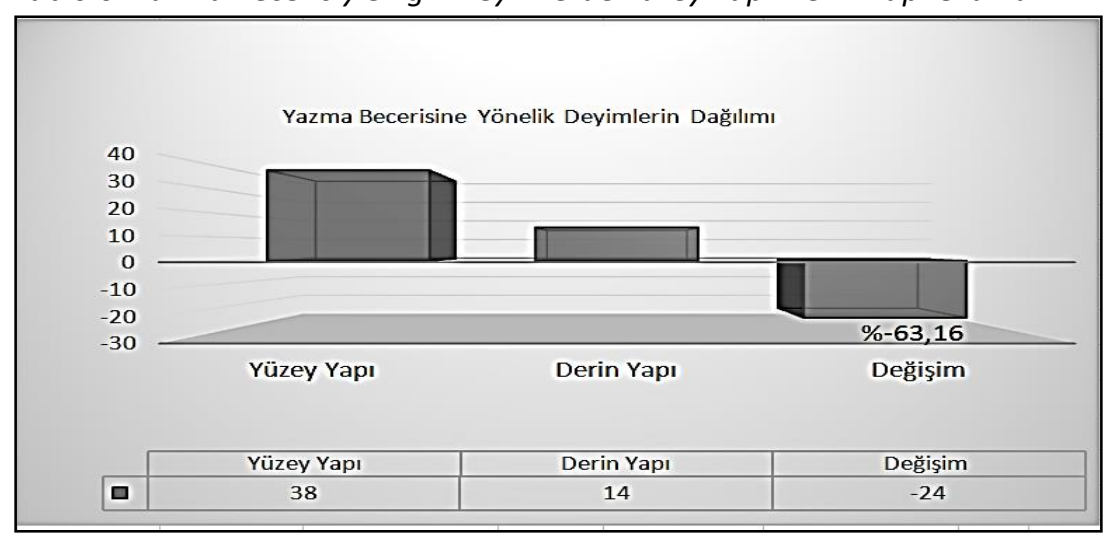

Yazma becerisiyle ilgili deyimler kendi içinde analiz edildiğinde, bu alanla ilgili deyimlerin genel olarak yazıya geçirme ve kayıt tutma kavramlarını terimleştirdiği görülmektedir. Kalem oynatmak, dikte etmek, kaleme almak, not tutmak, kayda geçmek, yazıya dökmek vb. deyimler bu durumu örneklendirmektedir. Bunların dışında sınırlı sayıda örnekle somutlaşan deyimler de mevcuttur. Bunların bir kısmı aşağıda sıralanmıştır.

Kaleminden çıkmak: Yazının bir kişiye ait olduğunu ifade ederken kullanılmaktadır.

Kaleminden kan damlamak: Kötü şeyler yazan kişiler için kullanılmaktadır.

Karınca duası: Küçük ve anlaşılmaz harflerle yazılmış bir yazıyı nitelerken kullanııır.

Eli kalem tutmak: Yazı yazabilen insanlar için kullanılmaktadır.

Kalem efendisi: Yazı yazmayı iyi derecede bilen insanlar için kullanılmaktadır.

Yazıyı sökmek: Yazı yazmayı öğrenmek anlamında kullanılmaktadır.

Tek örnekle ifade edilen deyimlerde yazma becerisinin davranış yönüyle ilgili sınırı sayıda deyimin yer aldığı görülmektedir. 


\section{Okuma Becerisi ile ilgili Deyimlere Ait Bulgular ve Yorumlar}

Dille ilgili deyimler içerisinde, okuma ile ilgili olanlar genel toplamın \%1.52'sini (8 adet) oluşturmaktadır. Okuma, dilin davranış katmanlarını ifade eden kavram alanı yönünden en az deyim grubuna sahip dil becerisidir. Çalışma kapsamında tespit edilen 8 adet okuma kavram alanıyla ilgili deyim, içerdikleri derin yapılar yönünden analiz edildiğinde, bu temel beceriye ait 6 farklı derin yapı tespit edilmiştir. Okuma becerisi ile ilgili deyimler genel toplamın \%3.47'sini oluşturmaktadır. Bu derin yapılar okuma alanıyla ilgili 6 farklı davranış katmanını temsil etmektedir ve okuma becerisinin dil farkındalığı düzeyini göstermektedir. Bu deyimler aynı zamanda Türkçedeki okuma kavramının sosyokültürel zeminini oluşturmaktadır. Okuma becerisinin davranış katmanlarını gösteren derin yapılar aşağıda sıralanmıştır.

Bülbül gibi okumak: Akıcı bir şekilde okumayı ifade eder. Okuma eğitimi terminolojisinde "akıcı okuma" kavramı mevcuttur. Akıcı okuma, "metindeki kelimeleri tanımak, metni belirli bir çabuklukta ve düzgün bir ifadeyle okumak demektir. Akıcı okuma, kelimenin hızlı tanınması, seslendirilmesi ve anlamının bulunması işlemleri sonucunda gerçekleşmektedir" (Güneş, 2007: 92). Su gibi okumak deyimi de aynı kavramı karşılamaktadır.

Göz gezdirmek: Bir metnin tamamını okumadan önemli kısımlarını seçerek okuma anlamında kullanılmıştır. Bu deyim de okuma eğitimi terminolojisinde göz atarak okuma adı altında kullanılmaktadır. Göz atarak okuma "konunun ayrıntılarına girmeden, ana hatlarıyla kavranması amacıyla yapılan okuma türüdür. Göz atarak okumada, metnin içeriğini anlamak ve istenen bilgiye ulaşmak için önce metnin başlığına bakılır; uzunluğu ve biçimi incelenerek metin şekil bakımından değerlendirilir. Metnin konusunu anlamak için gözler metin üzerinde hızlıca gezdirilir. Böylece ayrıntılar atlanarak ana fikre ulaşılmış olur (Özbay, 2007: 22). Gözden geçirmek deyimi de aynı anlamda kullanılmaktadır.

Kitap kurdu: Çok kitap okuyan insanlar için kullanılan bir deyimdir. Bu anlamı vurgulamak için sözlü ve yazıı dilde sıkça kullanılmaktadır. Dil eğitimi terminolojisinde çok kitap okuyan insanları tanımlamada kullanılan bir başka terim yoktur.

Mürekkep yalamak: Okuma yazma bilen öğrenim görmüş insanlar için kullanılan bir deyimdir. Sözlü ve yazılı dilde sık kullanılmaktadır.

Okumayı sökmek: Okumayı yeni öğrenmiş olan kişiler için kullanılmaktadır. Dil eğitimi terminolojisinde bu insanlar için genel anlamda okuryazar olma ifadesi kullanılmaktadır.

lç̧inden okumak: Sessiz bir şekilde okuma eylemini ifade etmektedir. Dil eğitimi terminolojisinde sessiz okuma şeklinde geçmektedir. Sessiz okuma, "kelimeleri ve cümleleri seslendirmeden gözle takip ederek yapılan okumadır. Bu okuma türünde ses telleri, ses dalgaları, dil ve kulak okuma sürecinden çıkarılmaktadır" (Güneş, 2007: 156). Içinden okumak deyimi hemen 
hemen sessiz okuma terimiyle aynı sıklıkta dil eğitiminde kullanılmaktadır. İçinden okumak deyiminin “ezberindeki şeyi aklından geçirerek tekrar etmek anlamı da vardır (Aksoy, 1995: 869).

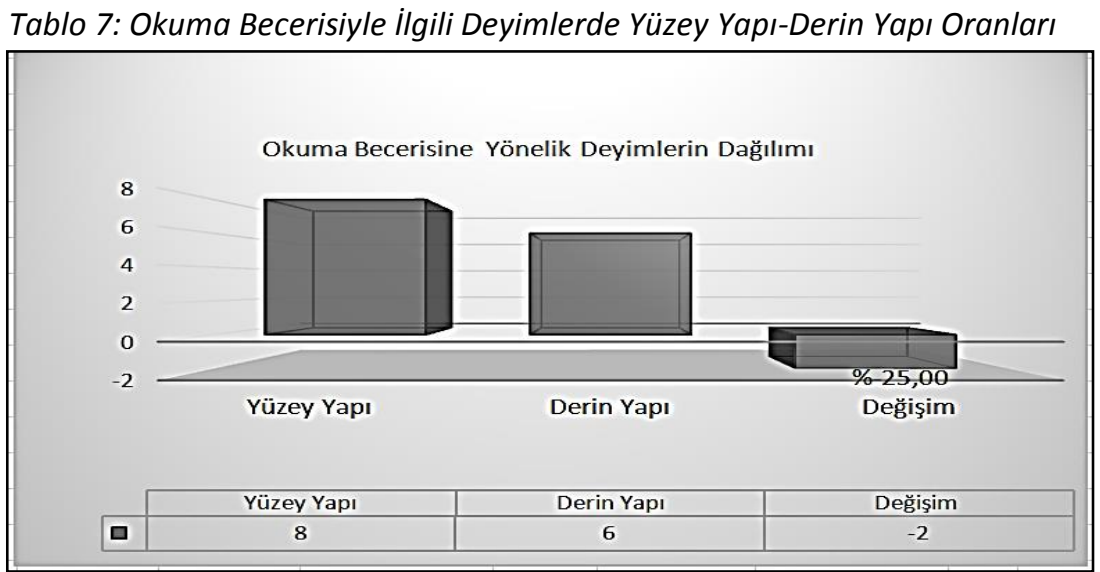

Okuma becerisiyle ilgili derin ve yüzey yapılar karşılaştırıldığında, bu iki temel yapı arasında \%-25.00 oranında bir değişim olduğu görülmektedir. Derin yapı ve yüzey yapı bakımından en az fark, okuma becerisiyle ilgili deyimlerde tespit edilmiştir. Okuma becerisiyle ilgili deyimlerin tamamı okuma eğitimi literatüründe yaygın olarak kullanılmaktadır.

\section{Sonuç}

Türkçe deyimlerde dil farkındalığı ve işlevsel dil kullanımı üzerine yapılan bu çalışmada şu sonuçlara ulaşılmıştır:

Çalışma kapsamında, Türkçede dille ilgili olan 526 deyim tespit edilmiştir. Bu deyimler konuşma, dinleme, yazma ve okuma dil becerilerinin kavram alanlarından birine girmektedir. Derin yapı ve yüzey yapı özellikleri yönünden en fazla deyim grubunun sırasıyla konuşma, dinleme, yazma ve okuma becerilerine ait olduğu tespit edilmiştir.

Tablo 8: Deyimlerin Genel Yüzey ve Derin Yapı Dağılımları

\begin{tabular}{lrrrr}
\hline Dil Becerisi & YY & \% & DY & \% \\
\hline Konuşma & 423 & 80.42 & 121 & 69.94 \\
Dinleme & 57 & 10.84 & 32 & 18.50 \\
Yazma & 38 & 7.22 & 14 & 8.09 \\
Okuma & 8 & 1.52 & 6 & 3.47 \\
Genel Toplam & $\mathbf{5 2 6}$ & $\mathbf{1 0 0}$ & $\mathbf{1 7 3}$ & $\mathbf{1 0 0}$ \\
\hline YY: Yüzey Yapı & DY: Derin Yapı & & &
\end{tabular}

YY: Yüzey Yapı DY: Derin Yapı

Yukarıdaki tabloda da görüldüğü gibi, dille ilgili deyimlerde 526 adet yüzey yapı 173 derin yapıyla temsil edilmiştir. Bu durum, dille ilgili deyimlerde bir davranış katmanının çok sayıda yüzey yapıyla dile getirildiğini göstermektedir.

Deyimler, dil eğitimi kitaplarında yer almayan ama sözcelem ortamında kişileri karşılaşabilme olasılıkları olan durumlara karşı hazır hâle getiren bir işleve sahiptir. Bu hazır bulunuşluluk ortamını deyimlerin terimleştirme özelliği sağlamaktadır. 
Deyimler, temel dil becerilerinin davranış katmanlarını terimleştirme işlevine sahiptir. Bu terimler belirli bir bilim alanına ait olmayıp halkın dilinde sürekli olarak kullanılan ifadelerdir. Bu açıdan bakıldığında deyimler, dilin davranış yönünü temsil eden durumları bilimsel terminolojinin dışında ikinci bir dil olarak kodlamaktadırlar. Temel dil becerilerinin davranış yönüyle ilgili bazı durumların deyimsel ifade dışındaki karşılıkları oldukça uzun tanım ve açıklamalarla yapılmaktadır. Terimleştirme bu noktada pratik bir ifade olanağı sağlamaktadır.

Deyimlerin terimleştirme işlevlerinden ders kitaplarında da yararlanılmalıdır. Ders kitaplarındaki metinlerde ve etkinliklerde bu tür deyimlere yer verilmeli, dilin davranış katmanlarını kazandırmaya yönelik çalışmalarda temel dil becerileriyle ilgili deyimlerden özellikle de konuşma becerisiyle ilgili olanlardan yararlanılmalıdır. Bu durumla bağlantılı olarak, konuşma becerisiyle ilgili deyimlerin derin yapı-yüzey yapı özellikleri yönünden konuşmanın davranış katmanlarını ayrıntılı bir şekilde ortaya koyabilecek niteliklere sahip olduğu tespit edilmiştir. Bu durum bir ifade zenginliğini de beraberinde getirmektedir. Konuşma ile ilgili deyimlerin bu ifade olanaklarından yararlanılmalıdır. Sınıf ortamında yapılacak anlam alanı ve çağrışım alanı çalışmalarıyla deyimlerin sözcelem ortamındaki kullanımlarıyla ilgili tartışmalar yapılmalıdır. Öğrencilerin dikkatleri metin içerisindeki kullanım bağlamlarına çekilmelidir. Deyimlerin anlamlarından yola çıkılarak dramatizasyon çalışmaları yaptırılmalıdır.

Sonuç olarak öğretmenler, dilin kavram alanına dâhil olan deyimlerin temel dil becerileriyle ilgili davranış özelliklerini kazandırmada kullanılabileceği hususunda bir farkındalık geliştirmelidirler.

\section{Kaynakça}

Aksan, D. (1999). Türkçenin gücü. Ankara: Engin Yayınevi.

Aksoy, Ö. A. (1995). Atasözleri ve deyimler sözlüğü I. İstanbul: İnkılâp Kitabevi.

Aksoy, Ö. A. (1995). Atasözleri ve deyimler sözlüğü II. İstanbul: İnkılâp Kitabevi.

Büyükkantarcıŏlu, N. (2003). Dil farkındalığı ve işlevsel dil kullanımı bağlamında anadilimiz: gözlemler, öneriler". Cumhuriyetimizin 80. Yllında Türkçemiz. Ankara: Ankara Ticaret Odası ve Anadolu Çağdaş Eğitim Vakfı, 19-26.

Büyükkantarcığlu, N. (2006). Toplumsal gerçeklik ve dil. İstanbul: Multilingual Yayınları.

Büyüköztürk, Ş., Kılıç Çakmak, E., Akgün, Ö, E., Karadeniz, Ş. ve Demirel, F. (2008). Bilimsel araştırma yöntemleri. Ankara: Pegem Akademi Yayıncılık.

Draaısma, D. (2007). Bellek metaforları. İstanbul: Metis Yayınları.

Elçin, Ş. (2005). Halk edebiyatına giriş. Ankara: Akçağ Yayınları.

Güneş, F. (2007). Türkçe öğretimi ve zihinsel yapılandırma. Ankara: Nobel Yayınevi.

Karasar, N. (2009). Bilimsel Araştırma Yöntemi. Ankara: Nobel Yayın Dağııım.

Millî Eğitim Bakanlığı. (2001). Türk atasözleri ve deyimleri Il. İstanbul: Millî Eğitim Bakanlığı Yayınları.

Onan, B. (2011). Türk atasözlerinde dil farkındalığı ve işlevsel dil kullanımı. Millî Folklor Dergisi, 91, 91-100. 
Türkçe Deyimlerde Dil Farkındalığı ve İ̧levsel Dil Kullanımı

Onan, B. ve Tiryaki E. N. (2012). Türkçede örtülü anlam oluşturan unsurlar ve ana dili öğretimindeki işlevleri. Mustafa Kemal Üniversitesi Sosyal Bilimler Enstitüsü Dergisi, 9 (19), 223-240.

Özbay, M. (2007). Özel öğretim yöntemleri II. Ankara: Öncü Kitap.

Saraçbaşı M. ve Minnetoğlu İ. (2002). Örnekli ve açıklamalı Türkçe deyimler sözlüğü. İstanbul: Bilge Kültür Sanat Yayınları. Türk Dil Kurumu. (1995). Türkçe sözlük. Ankara: Türk Dil Kurumu Yayınları.

Yurtbaşı, M. (2012). Sınıflandırılmış deyimler sözlüğü. İstanbul: Excellence Publishing. 


\section{Ek: Araştırmaya Temel Teşkil Eden Deyimlerin Listesi}

1 abuk subuk söylemek

2 abur cubur söylemek

3 açığa vurmak

4 açık konuşmak

5 adını anmamak

6 ağır işitmek

7 ağır söz

8 ağız açmamak

9 ağız açtırmamak

10 ağız ağıza vermek

11 ağız birliği etmek

12 ağız dalaşı

13 ağız değiştirmek

14 ağız dil vermemek

15 ağız dolusu

16 ağız eğmek

17 ağız kahyası

18 ağız kalabalığı etmek

19 ağız kavafı

20 ağız satmak

21 ağız şakası

22 ağız tamburası çalmak

23 ağız yapmak

24 ağız yaymak

25 ağızda sakız gibi çiğnemek

26 ağızdan kapmak

27 ağızdan laf çalmak

28 ağızdan laf çekmek

29 ağızlara sakız olmak

30 ağızları uymak

31 ağza almamak

32 ağza kilit vurmak

33 ağzı bir olmak

34 ağzı bozuk olmak

35 ağzı cıvık olmak

36 ağzı dili olmamak

37 ağzı gevşek olmak

38 ağzı kalabalık olmak

39 ağzı kara olmak

40 ağzı kulağına yakın olmak

41 ağzı laf yapmak

42 ağzı pek olmak

43 ağzı pis olmak

44 ağzı sıkı olmak

45 ağzı var dili yok olmak

46 ağzına (önüne) kemik atmak

47 ağzına almamak

48 ağzına aptesle almak (birini adını)

49 ağzına bakmak

50 ağzına baktırmak

51 ağzına geleni söylemek

52 ağzına kira istemek

53 ağzına taş almamak

54 ağzında (yar) yaş kalmamak

55 ağzında ayran durmamak
56 ağzında bakla ıslanmamak

57 ağzında mercimek durmamak

58 ağzından baklayı çıkarmak

59 ağzından bal akmak

60 ağzından bal damlamak

61 ağzından çıkanı kulağı duymamak

62 ağzından çıkanı kulağı işitmemek

63 ağzından dökülmek

64 ağzından düşürmemek

65 ağzından kaçırmak

66 ağzından laf almak

67 ağzından söz dirhemle çıkmak

68 ağzını açıp gözünü yummak

69 ağzını açmamak

70 ağzını bağlamak

71 ağzını bıçak açmamak

72 ağzını bozmak

73 ağzını hayra açmak

74 ağzını kapamak

75 ağzını kiraya vermek

76 ağzını kullanmak (birinin)

77 ağzını öpmek

78 ağzını satmak

79 ağzını toplamak

80 ağzını tutmak

81 ağzını yoklamak

82 ağzının gevişi olmak

83 ağzının içine bakmak

84 ağzının içine baktırmak

85 ağzının kalayını vermek

86 ağzının otunu vermek

87 ağzının ölçüsünü vermek

88 ağzının payını vermek

89 ağzının perhizi olmamak

90 ahfeşin keçisi gibi baş sallamak

91 ahkam kesmek

92 ahret suali sormak

93 akım derken b...kum demek

94 aldırış etmemek

95 atıp tutmak

96 attığı attık tuttuğu tuttuk olmak

97 avaz avaz bağırmak

98 bahis açmak

99 baltayı taşa vurmak

100 başbaşa vermek

101 başının etini yemek

102 beyaza çekmek

103 bildiğini okumak

104 bilmediğin söze karışmamak

105 bilmiş gibi söylemek

106 bin işitip bir söylemek

107 bir araba laf etmek

108 bir ayak üstünde bin yalan söylemek

109 bir ayak üstünde bin yalanın belini bükmek

110 bir bardak suda fırtına koparmak 
111 bir çift söz etmek

112 bir dediği iki olmamak

113 bir dereyi bal bir dereyi yağ etmek

114 bir kulağı yerde olmak

115 bir kulağından girip öteki kulağından çıkmak

116 bir nalına bir mıhına vurmak

117 bir sözünü iki etmemek

118 bire bin katmak

119 borusu ötmek

120 boş bulunmak

121 burnunu sokmak

122 buz üstüne yazı yazmak

123 bülbül gibi konuşmak

124 bülbül gibi okumak

125 bülbül gibi ötmek

126 bülbül kesilmek

127 büyük söz söylemek

128 büyük söze tövbe etmek

129 büyük yemin etmek

130 can kulağıyla dinlemek

131 car car etmek

132 cır cır ötmek

133 çam devirmek

134 çan çan etmek

135 çekip çekiştirmek

136 çekiye gelmemek

137 çene çalmak

138 çene patlatmak

139 çene yarıştırmak

140 çene yormak

141 çeneleri kilitlenmek

142 çenesi açılmak

143 çenesi durmamak

144 çenesi düşmek

145 çenesi düşük

146 çenesi kuvvetli olmak

147 çenesi tutulmak

148 çenesine üşenmez

149 çenesini açmak

150 çenesini bıçak açmamak

151 çenesini tutmak

152 çıkış yapmak

153 çıt çıkarmamak

154 çıt çıkmamak

155 dağdan taş yuvarlar gibi laf söylemek

156 daktilo etmek

157 daktiloya çekmek

158 davul çalsa işitmemek

159 dediği dedik olmak

160 defter tutmak

161 deli dolu söylemek

162 dem vurmak

163 demir yalayıp ateş püskürmek

164 derdini dökmek

165 dereden tepeden konuşmak

166 dert yanmak

167 dırdır etmek
168 dırıltı çıkarmak

169 dikte etmek

170 dil ağız vermemek

171 dil dökmek

172 dil ebesi

173 dil otu yemiş olmak

174 dil persengi

175 dil satmak

176 dil uzatmak

177 dil yarası

178 dilden dile dolaşmak

179 dile düşmek

180 dile gelmek

181 dile getirmek

182 dile kolay

183 dile vermek

184 dili açılmak

185 dili ağırlaşmak

186 dili bir karış dışarı çıkmak

187 dili bir karış olmak

188 dili çalmak

189 dili çözülmek

190 dili damağı kurumak

191 dili damağına yapışmak

192 dili dolaşmak

193 dili dönmemek

194 dili durmamak

195 dili ekmekçi küreği kadar uzun olmak

196 dili güllü olmak

197 dili kısa kulağı delik olmak

198 dili kurumak

199 dili sürçmek

200 dili takılmak

201 dili tutulmak

202 dili uzun olmak

203 dili varmamak

204 dili zifir olmak

205 dilinde tüy bitmek

206 dilinden düşürmemek

207 dilinden kurtulamamak

208 diline dolamak

209 diline kira istemek

210 diline şeker ezmek

211 diline yörük

212 dilini açmak

213 dilini bağlamak

214 dilini kedi yemek

215 dilini kesip oturmak

216 dilini kesmek

217 dilini tutmak

218 dilini yutmak

219 dilini zaptetmek

220 dilinin altında bir şey olmak

221 dilinin altındaki baklayı çıkarmak

222 dilinin bağı çözülmek

223 dilinin belasını çekmek

224 dilinin cezasını çekmek 
225 dilinin perhizi olmamak

226 dilinin ucuna gelmek

227 dilinin ucunda olmak

228 diliyle belaya uğramak

229 diliyle sokmak

230 diliyle tuzağa düşmek

231 diliyle yakalanmak

232 dillerde dolaşmak

233 dillerde gezmek

234 dillere destan olmak

235 dillere düşmek

236 dilli düdük

237 diyalog kurmak

238 diyeceği olamamak

239 diyolog kurmak

240 dobra dobra konuşmak

241 dut yemiş bülbüle dönmek

242 dünya kelamı etmek

243 edebiyat yapmak

244 eğri oturup doğru konuşmak

245 eğri oturup doğru söylemek

246 eğri oturup doğru söyleşmek

247 eğrisi doğrusuna denk gelmek

248 el aman çağırmak

249 eli kalem tutmak

250 eşek arısı gibi vızlamak

251 evelemek gevelemek

252 felsefe yapmak

253 fiskos etmek

254 gaf yapmak

255 gam almamak

256 gem almamak

257 gevezelik etmek

258 gık dememek

259 gönül okşamak

260 göz gezdirmek

261 gözden geçirmek

262 habbeyi kubbe etmek

263 hasbihal etmek

264 havadan sudan konuşmak

265 hazır cevap olmak

266 her itin dilini bilmek

267 her kafadan bir ses çıkmak

268 hesap tutmak

269 hık mık etmek (demek)

270 hitapta bulunmak

271 hoşbeş etmek

272 höt demek

273 içinden okumak

274 içini boşaltmak

275 içini dökmek

276 iki çift laf etmek

277 iki çift söz etmek

278 iki çift söz söylemek

279 iki sözü bir araya getirememek

280 ileri geri konuşmak

281 ileri geri söylemek
282 ileri gitmek

283 insan eti yemek

284 inşa etmek

285 işitmezlikten gelmek

286 işkembeden atmak

287 kadınlar hamamına dönmek (bir yer)

288 kafadan atmak

289 kafası şişmek

290 kafasına girmek

291 kağıda dökmek

292 kağıda sarılmak

293 kağıt üzerine dökmek

294 kalem çalmak

295 kalem efendisi

296 kalem oynatmak

297 kaleme almak

298 kaleme dökmek

299 kaleme gelmemek

300 kaleme sarılmak

301 kaleminden çıkmak

302 kaleminden kan damlamak

303 kargacık burgacık

304 karı ağızıı olmak

305 karınca duası

306 karış karış dili olmak

307 karşılık vermek

308 kayda geçirmek

309 kayda geçmek

310 kazı koz anlamak

311 kem küm etmek

312 kendi ağzıyla tutulmak

313 kırılıp dökülmek

314 kısa kesmek

315 kitap kurdu

316 konferans vermek

317 koyun kaval dinler gibi dinlemek

318 kulağı bende aklı başka yerde

319 kulağı delik olmak

320 kulağı düşük olmak

321 kulağı kirişte olmak

322 kulağına çalınmak

323 kulağına davul çalınmak

324 kulağına girmek

325 kulağına koymak

326 kulağına kurşun akıtmış olmak

327 kulağına küpe olmak

328 kulağına söylemek

329 kulağından gebe etmek

330 kulağını açmak

331 kulağını dikmek

332 kulak ardı etmek

333 kulak arkasına almak

334 kulak asmak

335 kulak dolgunluğu

336 kulak kabartmak

337 kulak kesilmek

338 kulak misafiri olmak 
339 kulak tıkamak

340 kulak tutmak

341 kulak vermek

342 kulakları dolmak

343 kulakları paslanmak

344 kulakları üstüne yatmak

345 kulaklarını tıkamak

346 kulaklarının pasını gidermek

347 kulakta tutmak

348 kulaktan dolma

349 kulaktan kapmak

350 kulaktan kulağa

351 kuru gürültü

352 kuru iftira

353 küfürü basmak

354 külahına anlatmak

355 laf ağzında kalmak

356 laf altında kalmamak

357 laf atmak

358 laf düşmemek

359 laf ebesi

360 laf etmek

361 laf işitmek

362 laf kaldırmamak

363 laf kıtlığında asmalar budamak

364 laf taşımak

365 lafa tutmak

366 lafı ağzına tıkamak

367 lafı ağzında çevirmek

368 lafı ağzında gevelemek

369 lafı ağzında kalmak

370 lafı ağzından çıkarmak

371 lafı çevirmek

372 lafı uzatmak

373 lafın belini kırmak

374 lafını bilmek

375 lafını etmek

376 lakırdı ağzından dirhemle çıkmak

377 lakırdı ağzından dökülmek

378 lakırdı altında kalmamak

379 lakırdı kavafı

380 lakırdı taşımak

381 lakırdı yetiştirmek

382 lakırdısını bilmek

383 lakırdısını etmek

384 lakırdıyı ağzına tıkamak

385 lakırdıyı ağzında çevirmek

386 lakırdıyı ağzında gevelemek

387 lakırdıyı çiğnemek

388 leb demeden leblebiyi anlamak

389 lisana gelmek

390 lügat paralamak

391 mangalda kül bırakmamak

392 martaval atmak

393 masal okumak

394 maval okumak

395 mürekkep yalamak
396 müsvedde yapmak

397 ne selam ne sabah olmak

398 not almak

399 not düşmek

400 not etmek

401 not tutmak

402 nutku kurumak

403 nutku kurumak

404 nutku tutulmak

405 nutuk atmak

406 nutuk söylemek

407 nutuk vermek

408 okumayı sökmek

409 ortadan söylemek

410 ortaya söylemek

411 özü sözü bir olmak

412 palavra atmak

413 pot kırmak

414 put gibi olmak

415 put kesilmek

416 rest çekmek

417 sadede gelmek

418 sağır sultan bile duymak

419 sakalı ele vermek

420 sapartayı yemek

421 sayıp dökmek

422 selam söylemek

423 ser verip sır vermemek

424 ses çıkarmamak

425 ses çıkmamak

426 ses vermemek

427 sesi soluğu çıkmamak

428 sesini çıkarmamak

429 sesini kesmek

430 sır küpü olmak

431 sohbetine doyum olmamak

432 söylemesi ayıp olmak

433 söylev vermek

434 söz açmak

435 söz ağzından dirhemle çıkmak

436 söz ağzından dökülmek

437 söz almak

438 söz altında kalmamak

439 söz anlamak

440 söz aramızda

441 söz arasında

442 söz atmak

443 söz ayağa düşmek

444 söz birliği etmek

445 söz dinlemek

446 söz düşmemek

447 söz ebesi

448 söz ehli

449 söz eri

450 söz geçirmek

451 söz işitmek

452 söz kaldırmamak 
453 söz meclisten dışarı olmak

454 söz sahibi olmak

455 söz tutmak

456 söz vermek

457 sözü (birşeye) getirmek

458 sözü açılmak

459 sözü ağzına tıkamak

460 sözü ağzında çevirmek

461 sözü ağzında gevelemek

462 sözü bağlamak

463 sözü çevirmek

464 sözü çiğnemek

465 sözü geçmek

466 sözü hasır altına gitmek

467 sözü kesmek

468 sözü sakalına geçmemek

469 sözü sohbeti çekilir

470 sözü sözüne uymamak

471 sözü yere düşmek

472 sözün arkasını kesmemek

473 sözünde durmak

474 sözüne aldırmak

475 sözüne gelmek

476 sözüne önem vermek

477 sözünü bilmek

478 sözünü esirgemek

479 sözünü etmek

480 sözünü geri almak

481 sözünü sakınmak

482 sözünü tutmak

483 sözünü yemek

484 sözünün eri olmak

485 su gibi okumak

486 suspus olmak

487 sürçü lisan etmek

488 süt dökmüş kedi gibi olmak

489 şom ağızı ılmak
490 şom ağzını açmak

491 şundan bundan konuşmak

492 tape etmek

493 taş atmak (birine)

494 taş kesilmek

495 taşı gediğine koymak

496 tatlı dilli

497 tatlı dilli olmak

498 tek kelime etmemek

499 telif etmek

500 temize çekmek

501 temize çekmek

502 tıraş etmek (çok laf etmek anlamında)

503 toz kondurmamak

504 ulu orta söz söylemek

505 uzun etmek

506 uzun lafın kısası

507 uzun sözün kısası

508 uzun uzadıya

509 üstü kapalı konuşmak

510 verip veriştirmek

511 vıdı vıdı etmek

512 yabana söylemek

513 yalan atmak

514 yalan yere yemin etmek

515 yarım ağızla söylemek

516 yazıp çizmek

517 yazıya dökmek

518 yazıya geçirmek

519 yazıyı çıkarmak

520 yazıyı sökmek

521 yüksek perdeden konuşmak

522 yüksekten atmak

523 zabıt tutmak

524 zapta geçmek

525 zehir zemberek

526 zülfü yare dokunmak 